\title{
Pedagogic Spaces and Identities: Film as Text
}

\author{
Mini Mark Bonjour*
}

\begin{abstract}
This article aims to explore pedagogic spaces in autonomous institutions and the identities they enable. It situates this exploration in the undergraduate General English classrooms and works with the uses of differing printed-literary and audio-visual media. It also attempts to show how both writing as text and film as text have equal value in undergraduate classrooms. Films, it is proposed, can be more than supplementary/ complementary texts to the much more conventional written-printed ones. They can and ought to occupy an equally privileged position in the teaching-learning process because they provide possibilities for critical understanding and engagement inside the classroom space. It is also argued that films have serious academic and learning potential than is often presumed to be. The article employs for its analysis reports of reception of films within a pedagogic space from student-respondents. In the process of the analysis, the article seeks to construe how classrooms become pedagogic spaces for identity constructions. By way of conclusion, the article comments on the various ways in which films as texts shape critical thinking and self-critique.
\end{abstract}

Keywords: Film, Pedagogy, Classroom; Identities, Popular culture

\section{Introduction}

Classrooms in an autonomous college set-up, particularly in the case of general English classes, lend themselves to be moulded by a

*St Joseph's College, Bengaluru, India; at minimarkb@gmail.com 
curriculum designed by the teacher, which is drawn keeping in mind the students' learning needs and the course objectives for each semester. Classroom spaces are powerful arenas where pedagogic approaches and strategies shape the progressive discernment of students. These can therefore be expected to create a culture of reflection and debate as well as to enable the reshaping of perspectives and identities. It is vital for the health of democracies that their educational systems promote free thought, fearless expression of opinion, respect for the right to differ, and an overall respect for plurality. The purpose of the action research presented in this article is to examine the extent to which these ideals are realisable in the undergraduate classroom through the use of film screenings that generate debate and discussion.

For the purpose of the study twenty-two films were screened in General English periods for the first and second year B.A and B.Sc classes at St. Joseph's College, where I teach. These comprised six undergraduate classes taught by me during a two year period (from June 2015 to March 2017). The general methodology comprised film screening sessions alternating with debate/discussion/reflection sessions. To initiate discussion, the students were asked to give in questions (in written form) that arose in their minds immediately after the viewing experience. These questions were then taken up for discussion in the following session. The range of discussion that ensued from the screening of the various films is also presented here as evidence for the emergence of a critical/reflective classroom ethos. At the end of each semester I also asked for feedback on the overall experience from students. I have also drawn on this feedback for the purpose of this article.

\section{Classroom spaces}

Classrooms these days are heterogeneous, with students coming from diverse cultural backgrounds. Curricula in schools, however, have been too rigidly framed to creatively exploit this diversity for pedagogic purposes. Very rarely have textbook makers allowed students to jump out of the clichéd box. In a few autonomous colleges, however, which respond to student diversity by streaming them according to learning needs, General English language 
learning classrooms provide possibilities for texts such as songs, films, documentaries, Ted Talks, YouTube videos and so on to supplement/complement reading material as well as themselves performing as primary texts. This approach goes a long way in helping students expand their linguistic, intellectual and cultural horizons and build more nuanced identities that fit them better to function in plural, secular and democratic spaces.

Many forms of entertainment have great potential for linguistic and intellectual exploitation in the English classroom. Ever since the advent of mass culture in the early $20^{\text {th }}$ Century, popular forms of entertainment-cinema, recorded music, magazines and comicshave been staples in the lives of youngsters and have been very influential in creating youth culture. The modes of entertainment evolved significantly over the decades before the advent of television. Much entertainment in the pre-TV era depended on the print media. There was very little one did in one's free time than read books and magazines. If one was excited about film celebrities and was in the throes of becoming a film buff, as was the case with this writer, one would pour over magazines with pictures of actors from Bollywood and regional cinema. These glossies were expensive to possess and most of them would be procured from circulating libraries. The magazines would range from Cine Blitz, Filmfare, Screen, Stardust, Star $\mathcal{E}$ Style, to Chalachithram, Chithrabhumi, Nana, Vellinakshatram, etc.i The regular movie goer zealously connected faces of film celebrities as seen in film magazines with their respective faces in the movies that they watched in theatres.

The late 1980s saw the advent of television in Indian homes. Film enthusiasts could sit in the comforts of their homes and watch with gusto these celebrities receiving awards for their contribution to Cinema. When cable TV operators revolutionised entertainment as an everyday occurrence in Indian homes, films had come to stay. As a result, film aficionados were drawn to everything that nuanced cinema: actors, roles, costumes, sets, cinematography, direction, script, music, dance and even film-associated gossip. Such enthusiasts would magically arrive at answers to questions regarding films, inclusive of trivia. In my own case, the craze for films found me doing research and academic work in this area. 
This soon led to the discovery of films holding a very significant role in configuring spaces and identities in classroom pedagogy. Classroom pedagogy enables parallels to be drawn between reel and real. Often this interrelation between reel and real turns the classroom space into one where the power of film as text can be experienced first-hand thus furthering it as an important and emerging area of academic interest.

As a result, film can be seen as a powerful educational tool, centred on young people's learning experiences. In fact, the very term presents an opportunity to engage in etymological exploration. It is interesting to note that the word film has undergone change from "a thin membrane" in the 1570s to "the coating of chemical gel on photographic plates" in 1845. By 1985 film also came to mean "the coating plus the paper or celluloid." In 1905 it became "motion picture." From 1920 it came to mean "film-making as a craft or art" From 1899 film no longer meant a noun but it was also used as a verb ("to make a movie of"). From 1920 it began to be used in the sense of "film-making as a craft or art"(Film, 2000.).ii The ability of the human brain to recollect images perceived by the eye for a brief period of time even after they recede from eyesight was known since the time of the ancient Egyptians. However, it is not until the mid-19th century that entrepreneurs took advantage of this aspect for its "optical entertainment value" (Kupsc, 2006, p. 1). Since then, the definition of film has come a long way today with its nuanced connotations. Susan Hayward in Key Concepts in Cinema Studies (2013) is of the opinion that "Cinema is an ideological apparatus by nature of its very seamlessness. We do not see how it produces meaning-it renders it invisible, naturalises it. Mainstream or dominant cinema, in Hollywood or elsewhere puts ideology up onscreen" (p. 214).

A classroom reaches its peak potential only when pedagogy is presented in a variety of ways and when learning can be evaluated through diverse and alternative methods. Howard Gardner, the American Developmental Psychologist, in his book, Frames of Mind: The Theory of Multiple Intelligences (1988) believes that people have multiple intelligences and thus learning and assimilation do not happen in a uniform manner. He is of the view that all human beings are born with an array of intelligences which ought to be 
advanced by the social order, to realize boundless and specific achievements that would fulfill greater social objectives. In keeping with the spirit of this insight, departments of English across the world are moving into interdisciplinary spaces. A good example of this is the emerging field of study called Digital Humanities. At a time when vast databases and archives pertaining to the humanities comprise both written and multimedia texts, films as a subset of the Digital Humanities are now available in the widest possible range and are almost ubiquitous in terms of access. Their co-existence and co-dependence with other textualities open up vast new possibilities for more experiential and more immersive classroom learning. A film not only makes facts visually fascinating and arrests a person's attention with its cinematography and dialogue but generates possibilities of rich and varied articulation when it moves into the classroom space.

Tanya Clement, writing about the pedagogic potential of the digital humanities as a whole, states that "digital humanities can improve students' abilities to write and read the Web, to interpret, discern, and critique the Web, and ultimately, to be more engaged citizens in the world" (Clement, 2012).iii As a significant component of Digital Humanities today, filmic texts make richer multidimensional learning eminently possible.

As a teacher of English long committed to seeking ever newer ways of making the classroom experience as enriching as possible for my students, I have time after time found that filmic texts work synergistically in the classroom when brought into play alongside more traditional texts. My classroom practices with regard to film as text have helped me to reflect on their value not just as very effective stimuli for critical thinking and writing but as tremendous opportunities for opening up new avenues for value clarification, personal growth and character formation. In this article I draw upon my own experiences to demonstrate how films become texts in classes and how students engage intensely with them as discourse. Even when one is watching an adaptation of a book into a film, the film plays the book out on the screen giving one a fuller effect of comprehending the book. The students are drawn into the discourse of engaging with the author-auteur and the readerviewer politics. 


\section{Alternate texts}

The Encyclopædia Britannica defines motion picture as a "series of still photographs on film, projected in rapid succession onto a screen by means of light" (Stephenson et al., n. d.). iv According to Jean-Luc Godard the French-Swiss film director, screenwriter and film critic who is often identified with the 1960s French film movement La Nouvelle Vague, or French New Wave, "Photography is truth. Cinema is truth twenty-four times per second"(as cited in Gibbons, 2011).v He finds that both style and content go together and cannot be separated as "style is just the outside of content, and content the inside of style, like the outside and the inside of the human body" (as cited in Metabletician, 2012). vi

Having experimented with balancing the printed text with the audio-visual one, I have been able to derive that the latter works as primary, complementary/ supplementary texts. Primary texts are the prime/ chief texts used in a classroom. Complementary/ supplementary texts are additional and supporting texts that amplify the meaning of primary texts.

There are many ways in which these audio-visual materials can alternate as texts. Films work as texts for the very reason that they are starting points for conversations in classrooms, between students and students as well as between students and the teacher.

For instance, students from the first semester were given an extract from E. R. Braithwaite's To Sir with Love (2005) as primary text to read in class. The book is autobiographical in nature with the focus around Braithwaite's dedication as a teacher who turns the students around by breaking down barriers of racial prejudice. This was followed by the screening of the film adaptation of To Sir, with Love (Clavell, Sloan \& Clavell, 1967) and its sequel To Sir, with Love II (Stenta \& Bogdanovich, 1996) as complementary texts. Sidney Poitier (who plays the role of Braithwaite) in To Sir, with Love (Clavell, Sloan \& Clavell, 1967) was able to weave his magical spell through the London/ Chicago classrooms (to the Indian classrooms of the viewers) when he informs his students that "Sorry" and "Thank you" are "magical words". Some of the students were so inspired by Braithwaite's autobiography as portrayed in the film 
that they went back and read the book, thus demonstrating that far from wooing youngsters away from the printed page, film has the potential to act as appetizer for books and can be used to inaugurate a reading life. Tweaking Braithwaite's line from To Sir with Love, I would want to add that as long as we are willing to learn, it really does not matter what the medium is that teaches us (Braithwaite, 2005).

Another example that proves this point is the experience I made possible for my students with relation to an excerpt from The Diary of Anne Frank (1993) that I got them to read. In wanting to screen a film to complement their reading the easiest choice would have been one of the many versions of the film on Anne Frank (1959 to 2009). However, since I have been involved in curriculum making in an autonomous institution, I chose to screen the film Freedom Writers (DeVito, Shamberg, Sher \& LaGravenese, 2007), instead. The reason I did this was because I could tap this film resourcefully. Freedom Writers, (DeVito, Shamberg, Sher \& LaGravenese, 2007), first of all, was based on the diary entries in one widely sold book, The Freedom Writers Diary co-authored by Erin Gruwell and the Freedom Writers (1999). This is the true story of a young teacher Erin Gruwell, thrown into a class of integrated students during the Los Angeles Riots of 1992 at Woodrow Wilson High School in Long Beach. The diary entries were made by about one hundred and fifty of Gruwell's students. The film's title derives from "Freedom Riders", the title given to the mostly AfricanAmerican and "white" college students, who in 1961 took the ride in interstate buses into the segregated southern United States to assess newly, proclaimed civil rights laws.

\section{Impact on students}

The film impacted the students in the following five different ways.

Firstly, the students (both in the film and the audience watching it) were made to understand the tenacity of "Passive Resistance". Secondly, the students were able to connect diary writing to their own objectives of the General English Course in the first semester, of exploring personal writing and personal space. The students began to understand that it was normal for young people across 
various cultures to have angst and that they could wear their hearts on their sleeves and that it was alright to bare it all in their journals or blogs. They were able to understand how writing could become a powerful tool in enterprises of personal and social transformation. Thirdly, they were able to comprehend that the adult world need not necessarily be negatively predisposed to young people. The students were able to relate to Wilson's room 203 and their actual classroom in a palpable manner. Fourthly, the film helped them to see the close connections between the history of the past (Holocaust) and the present (dangers of impending wars). Finally, the students also picked up interesting trivia from their peers during the discussion that followed: Gruwell's founding of the non-profit organization, The Freedom Writers Foundation, which functions to promote Erin's successful teaching methods; and that Erin was given the Spirit of Anne Frank Award due to her commitment to her students and teaching. The excitement of peer learning that happens during the post-film discussion in the classrooms is something that the students look forward to. As stated earlier, students were able to use films as texts where they responded to questions of race and how racism is a pervasive system and not merely a phenomenon affecting individuals. They were engaged in semiotics and in creating a mimetic of a Gruwell/ Brathwaite classroom.

A student evaluation at the end of every semester ensures that the classroom spaces do not stagnate but posit growth. Thus, I have firmly begun to believe that I must end every semester with an evaluation, where the undergraduate students are free to critique my classes in terms of the content, methodology and atmosphere. Most of the students have offered positive feedback and I have included in this article a few of their responses. One of my students, Drishti Rakhra, in her evaluation, says that films as texts worked well in bridging the gap between the book and the film, especially for non-readers. Vinay Kumar, another student, is of the view that films screened during General English classes were both fun and educative and worked effectively as a teaching-learning tool. Shivani Shailesh, a student feels that film as a text helps one get multiple views. It also helps one to interpret things when one is not in the frame of mind to read the printed text. 
The objective of the second semester course is to engage with narratives and close reading. Screening of a film like The Raven (Evans, Macy, Ryder \& McTeigue, 2012), worked well in looking at the tales of mystery/ crime and the macabre as a genre of narrative, after reading Edgar Allen Poe's The Raven (n.d.). Reading Graphic novels like Marjane Satrapi's The Complete Persepolis (2004) made more sense with the screening of the film Persepolis (Rigault \& Robert, 2007; Paronnaud \& Satrapi, 2007) (in either French with English sub-titles or the dubbed version in English). Films like Memento (Todd, Todd \& Nolan, 2000) and He Loves Me... He Loves Me Not (2002) À la folie... pas du tout (original title) (Gassot \& Colombani, 2002) helped the students understand non-linear narratives. Sci-fi films like The Martian, (Goddard et al., \& Scott, 2015), 2001: A Space Odyssey (Kubrick, 1968), The Matrix, (Berman et al., 1999), The Matrix Reloaded (Berman et al., 2003), E Matrix Revolutions (Berman et al., 2003), were some of the films screened to complement readings from Science Fiction as part of narrative texts.

Seher Dareen, a B.A student writes that film-screening as a medium for education is more effective than just lectures or reading materials. As a student of the Humanities, she was part of the Special General English course, a Science Reading and Writing course that is offered as choice in the third semester. The classes deal with understanding the philosophy of science and thus involve a lot of reading and writing in the field of science. As earlier stated, diversity in text selection facilitates effective multidimensional learning in classroom spaces.

I have found that interspersing reading with a few science documentaries and films enhances lucidity in the conception of scientific facts. George Orwell's essay “What is Science?" (O. Dag, 1968) often sets off argumentative debates in class about science, religion and ethics in the context of World War I. A screening of the docu-drama Einstein and Eddington (Pybus \& Martin, 2008) enables students to comprehend the reading of Orwell's essay in an effective manner. The students watch the unravelling of the exciting and creative passion of two young scientists who were able to change scientific thinking the world over. They also understand how destructive and problematic science can be in the hands of 
fanatics. Debates about the ethics of Eugenics and cloning were better understood with the screening of Gattaca (DeVito, Shamberg, Sher \& Niccol, 1997) and The Island (Bay, Bryce, Parkes, \& Bay, 2005) respectively. The film screenings were followed by questions and answers that were scientifically stimulating and also posed important ethical questions about the nature of science. Thus, the objective of argumentative writing that was set forth in the third semester was achieved to a significant degree in the writing tasks assigned to them.

Another student, Mark Rassendren, is of the opinion that in Class 12, one was considered a student of English only if one had read a good amount of Shakespeare, some Greek Literature, some Dickens, and Hardy and so on. He opines that in most schools, very few teachers feel the need to explore other modes of teaching English. He is of the belief that English language classes are meant to teach language irrespective of the medium that is employed. Watching films during English classes actually worked for him as it helped him look at things from more than one perspective. For him a film was not very different from other works of literature and he felt that a film had all the elements a book possessed. A film puts all the literary devices that one has learnt about theoretically into audio-visual action which he feels is the USP and the beauty of a film. He is of the firm belief that films screened during English classes have worked for him both as primary and secondary texts.

The students who use conventional printed texts are limited to using only certain approaches to reading that text. Cinema (or other audio-visual texts/ digital humanities) on the other hand takes the idea of exposure further with the idea of intensifying the reading experience. Roshan Machayya, another student of mine, believes that true education is all about enriching experiences and exposures-social, academic, absurd and disturbing. The cinematic experience as an academic necessity fulfils a certain truth about arrangement, dynamics, composition, outlook, and influence. He believes that cinema as an academic experience ensures that the students examine the unexamined and thus perceive their own reality and truth(s) making it an entire discourse by itself.

Hirvanshi Malhotra, another of my students, is aware that students in her General English class would prefer a film to a printed text. 
She feels that the film is an excellent way of reaching out to the entire class. Some students with learning disabilities are also able to recollect what they have seen better than what they have read. However, she adds that relying only on films as text in an English class does not completely help in deep analysis of the topic. She thus firmly believes that printed texts should not be eliminated and that there should be a balance of both media.

Radhika Mukherji, another student, feels that a film can be viewed as a text, much like a novel. These too contribute to how a viewer experiences the film. Hence, they become a part of the text that the viewer reads. She looks at a film as a text, with all the other aspects like sound, camera, visuals, lighting, costumes, and so on adding to the overall general feeling the film presents her with, which she says plays a crucial role in her interpretation of the text.

General English students in the fourth semester who take up the regular course in the autonomous set-up are taught "controversion", the ability to mount a sustained argument against another perspective or engage in polemics. The students are encouraged to respond to questions of social justice, nationality, gender, language, race, religion, caste, marginalities and so forth. Students were also exposed to World cinema. The Saudi Arabian film Wajda (Meixner, Paul \& Al-Mansour, 2012), the Iranian film Stoning of Soraya M. (McEveety, Shepherd \& Nowrasteh, 2008) the Indian film Parzania (Dholakia, Donihue, Patel, Sareen \& Dholakia, 2007), are some of the films that I engaged the students with, in relation to topics mentioned earlier.

Bangalore Days (Paul, Rasheed \& Menon, 2014), Killa (McAlex, Musle, Rai, \& Arun, 2014), Aankhon Dekhi, (Mundra \& Kapoor, 2013), Gubbachigalu (Suresha, Nag \& Simha, 2008) were some of the regional films (all subtitled in English) screened during the fourth semester General English course offered as an elective/ special course or the Bangalore City Course. These were screened to enhance the understanding of economic, socio-political and historical culture of city spaces, especially of Bangalore City.

When students watch a film in class they are engaged in a collaborative and synergistic activity. Students benefit from peers voicing their opinions and most times are surprised that their 
friends had noticed things that they somehow had not noticed earlier. Students are made to see how the transition between the printed text and the screen takes place. Films thus make the distinction between "showing" and "telling" and thus enable students to have multiple perspectives in identifying situations, problems, and issues in "reel" as well as "real" life. When a few students welcome films as a refreshing change from the conventions of reading printed texts, some others are improving their diction and pronunciation from the English films being screened or are learning to listen to the regional languages while simultaneously engaging with English sub-titles. In all these ways, autonomous institutions do offer scope for innovation and a way of transcending the limitations of conventional pedagogy.

\section{Conclusion}

To conclude, classrooms are spaces for cultural identities to be augmented and transformed and sometimes re-defined and altered. Hence they become sites of discursive power where one set of power strategies jostles with another or assesses its powers in relation to others, often challenging and transforming one's own beliefs and ideas. Thus, these challenging or transforming moments in a classroom offer possibilities for self-critique that enhance learning for both students and teachers.

Films enhance a more effective mode of reaching out to students especially to those students who find reading tiresome as well as to those with learning disabilities but this should be balanced efficiently with reading printed texts as well.

It is time indeed to respect popular culture equally with literary texts and thus disrupt and subvert canons. The use of films as texts in classroom spaces has thus been a very educational and fulfilling experience as one cannot but help notice how screening of these films promotes creativity and free thinking among students in such tumultuous times as the one we are currently living in.

Classrooms are thus not vacuous and dormant spaces. They are spaces where power systems are at play, namely those of class, caste, gender and community. Films as texts become powerful tools that arbiter identities and alter ideologies. Media and technology 
recurrently re-construe what is said in the classrooms and in the public realm as well. Thus, classroom spaces are spaces of learning about history, culture and society. The cultural confrontations they throw up are momentous, for they promote self-reflexivity.

We can reasonably conclude then that cinema as a medium is a sensitive and creative enterprise with rich pedagogical potential when brought into a space where discussion and critique are feely promoted. When screened inside the classroom space, it allures the students with a "self-contained universe of dreams, passions, and fears - a place of suspended disbelief and possibilities without limits" (Kupsc, 2006, p. 368). What one brings to a film is important no doubt but what one takes away from it is perhaps much more so. The experience films provide helps participants enrich their inner lives, build more nuanced selves and journey from narrow perspectives and prejudices to broader horizons that are crucial to the formation of identities that are friendlier to a democratic and pluralist ethos. It is a journey away from fanaticism and chauvinism and at this hour India needs millions of its college going students to undertake this journey.

\section{References}

Braithwaite, E. R. (2005). To Sir with love. London: Vintage.

Frank, A. (1993). Anne Frank: The diary of a young girl. (B. M. Mooyaart, Trans.). New York, NY: Bantam Books.

Gardner, H. (2011). Frames of mind: The theory of multiple intelligences. (3rd ed.). United Kingdom: Hachette.

Gruwell, E., \& Writers, F. (1999). The freedom writers diary. United States of America: Random House.

Hayward, S. (2013). Key concepts in Cinema Studies (4th ed.). London/New York: Routledge.

Kupsc, J. (2006). The history of cinema for beginners. Chennai, India: Orient Longman Pvt Ltd.

Orwell, G. (1945). What is Science? (O. Dag, Machine-readable version, 1968.). Retrieved from http://orwell.ru/ library/articles/ science/ english/ e_scien

Poe, E. A. (n.d.). The raven. Retrieved from https:// www.poetryfoundation.org/ poems/ 48860/the-raven. 
Satrapi, M. (2004). The complete Persepolis (M. Ripa, B. Ferris \& A. Singh, Trans.). Toronto: Random House.

\section{Films}

Bay, M., Bryce, I., \& Parkes, W. F. (Producers), \& Bay, M. (Director). (2005). The Island [DVD]. USA: Dreamworks Video.

Berman, B., Forbes, D., Hill, G., Mason, A., Silver, J., Wachowski, L., \& Wachowski, A. (Producers), \& Wachowski, L., \& Wachowski, A. (Directors). (2003). Matrix Revolutions [DVD]. California, USA: Warner Home Video, Inc.

Berman, B., Forbes, D., Hill, G., Mason, A., Silver, J., Wachowski, L., \& Wachowski, A. (Producers), \& Wachowski, L., \& Wachowski, A. (Directors). (2003). The Matrix Reloaded [DVD]. California, USA: Warner Home Video, Inc.

Berman, B., Mason, A., Osborne, B. M., Silver, J., Stoff, E., Wachowski, L., \& Wachowski, A. (Producers), \& Wachowski, L., \& Wachowski, A. (Directors). (1999). The Matrix [DVD]. California, USA: Warner Home Video, Inc.

Clavell, J., \& Sloan, J. R. (Producers), \& Clavell, J. (Director). (1965). To Sir, with Love [DVD]. USA: Columbia TriStar Home Video.

DeVito, D., Shamberg, M., \& Sher, S. (Producers), \&LaGravenese, R. (Director). (2007). Freedom Writers [DVD]. USA: Paramount Home Entertainment.

DeVito, D., Shamberg, M., \& Sher, S. (Producers), \& Niccol, A. (Director). (1997). Gattaca [DVD]. USA: DVDBeaver.

Dholakia, R., Donihue, D. N., Patel, K., \&Sareen, K. B., (Producers) \& Dholakia, R. (Directors). (2005). Parzania [DVD]. New Delhi: Eagle Home Entertainment.

Evans, M. D., Macy, T., \& Ryder, A. (Producers), \&McTeigue, J. (Director). (2012). The Raven [DVD]. USA: 20th Century Fox Home Entertainment.

Gassot, C. (Producer), \&Colombani, L. (Director). (2002). He Loves Me... He Loves Me Not. À la folie... pas du tout (original title) [DVD]. USA: Columbia TriStar Home Video.

Goddard, D., Huffam, M., Kinberg, S., Schaefer, M., Scott, R., \&Sood, A. (Producers), \& Scott, R. (Director). (2015). The Martian [DVD]. Los Angeles, USA: 20th Century Fox Home Entertainment. 
Kubrick, S. (Producer), \& Kubrick, S. (Director). (1968). 2001: A Space Odyssey [DVD]. California, USA: Warner Home Video, Inc.

McAlex, A., Musle, M. R., \& Rai, A. (Producers), \& Arun, A. (Director). (2014). Killa [DVD]. New York, NY: Kino Lorber Home Video.

McEveety, S., \& Shepherd, J. (Producers), \&Nowrasteh, C. (Director). (2008). The Stoning of Soraya M. [DVD]. UK: Lionsgate home entertainment.

Meixner, G., \& Paul, R. (Producers), \& Al-Mansour, H. (Director). (2012). Wajda [DVD]. USA: The Criterion Collection.

Mundra, M. (Producer), \& Kapoor, R. (Director). (2013). AnkhonDekhi [DVD]. Mumbai, India: Shemaroo Entertainment Ltd.

Paul, S., \& Rasheed, A. (Producer), \& Menon, A. (Director). (2014). Bangalore Days [DVD]. Irinjalakuda, India: Movie Channel.

Pybus, M. (Producer), \& Martin, P. (Director). (2008). Einstein and Eddington [DVD]. PAL UK: Dolby digital.

Rigault, X., \& Robert, M. (Producers), \&Paronnaud, V., \& Satrapi, M. (Directors). (2007). Persepolis [DVD]. Culver City, California: Sony Pictures Home Entertainment.

Stenta, R. (Producer), \&Bogdanovich, P. (Director). (1996). To Sir, with Love II [DVD]. USA: Columbia TriStar Home Video.

Suresha, B., \& Nag, S. (Producers), \& Simha, A. (Director). (2008). Gubbachigalu [DVD]. Bengalooru, India: Total Kannada.

Todd, J., \& Todd, S. (Producers), \& Nolan, C. (Director). (2000). Memento [DVD]. USA: Sony Pictures Home Entertainment.

\section{End Notes}

i These were the film magazines available in Bangalore and Kerala in the 1980s. Cine Blitz, Filmfare, Screen, Stardust, Star \& Style were in English while Chalachithram, Chithrabhumi, Nana, Vellinakshatram were in Malayalam.

ii Film [Def. 1]. (2000). In Online Etymology Dictionary. Retrieved from http://www. etymonline.com/word/film

iii Clement, T. (2012). Multiliteracies in the Undergraduate Digital Humanities Curriculum: Skills, Principles, and Habits of Mind. In B. D. Hirsch (Ed.), Digital Humanities Pedagogy: Practices, Principles and Politics [Open Book Publishers]. Retrieved from https://www. openbookpublishers.com / htmlreader /DHP / main.html 
iv Stephenson, R., Murphy, A., Sklar, R., Manvell, R., \& Andrew, D. (n.d.). Motion picture. In Encyclopædia Britannica. Retrieved from https:// www.britannica.com/ art/motion-picture

v Gibbons, F. (2011, June 12). Jean-Luc Godard: 'Film is over. What to do?' In The Guardian. Retrieved from https:// www.theguardian.com/ film/ 2011/jul/12/jean-luc-godard-film-socialisme

vi Metabletician, T. (2012, March 3). The French New Wave and Jean-Luc Godard. Retrieved November 27, 2017, from,https:// metabletics.wordpress.com/2012/03/03/the-french-new-wave-andjean-luc-godard 